\title{
THE ACHIEVEMENT GOAL THEORY AS AN APPROACH TO STUDY SCHOOL PRINCIPALS' LEADERSHIP MOTIVATION
}

\author{
Christian Brandmo, Dijana Tiplic, Eyvind Elstad \\ University of Oslo, Oslo, Norway \\ E-mail: christian.brandmo@ils.uio.no, dijana.tiplic@ils.uio.no, \\ eyvind.elstad@ils.uio.no
}

\begin{abstract}
This study investigates how the achievement goal theory and its measures can be utilized to understand the school principals' achievement goals for leading. The achievement goal theory is an analytical tool little used when studying educational management. This explorative study aims at developing a measure of principals' achievement goals for leading, by using a factor analysis of the scores of 270 Norwegian principals. The analysis shows a clear distinction between principals' mastery and performance goals for leading. Mastery goals for leading were positively correlated with constructs such as principals' efficacy beliefs for leading, autonomy and teacher-principal trust, while performance goals were weaker or not significantly correlated with these constructs. The study suggests that the context and organizational factors are influencing principals 'purposes of achievement behaviour. Given the increasing emphasis on the accountability of school leaders, the current study suggests the achievement goal theory as a fruitful approach when studying educational leadership.
\end{abstract}

Key words: accountability, achievement goals, educational leadership, school leaders' motivation.

\section{Introduction}

Over the past thirty years, achievement goals (or goal orientation) have been the subject of much research in the field of educational psychology. One focus of research has been the consequences of various types of achievement goals on students' learning behaviour and academic achievement. Attention has also been paid to the personal and contextual factors that cause and influence different kinds of achievement goals. Given that many countries' educational systems have seen the introduction of assessment-based accountability policies (de Wolf \& Janssens, 2007) and that accountability of school leaders have increased, this study examines whether the construct of achievement goals is transferable to the context of educational leadership. The study applies Ames and Archer's integrative achievement goal theory (1988) that differentiates mastery goals from performance goals, as well as Elliot's (1999) distinction between approach and avoidance goals. The theoretical frame used in this study is the $2 \times 2$ achievement goal model (Elliot and MacGregor, 2001). With regard to the goals of school staff, there have been some studies of teachers' achievement goals. For instance, Butler (2007) and Retelsdorf, Butler, Streblow and Schiefele (2010) found a four-factor model of teacher achievement goals for teaching, but included work avoidance instead of mastery avoidance goals, which is a conceptually different construct. However, to our knowledge, none has tried to apply the $2 \times 2$ achievement goal model to the school leadership context. Therefore, this is an explorative study to develop a measure of principals' achievement goals for leading. 
Christian Brandmo, Dijana Tiplic, Eyvind Elstad. The Achievement Goal Theory as an Approach to Study School Principals' Leadership Motivation

EMS

OF EDUCATION

IN THE $21^{\text {st }}$ CENTURY

Volume 58,2014

\section{The Achievement Goal Framework}

Achievement goals concern an individual's pursuit of competence and the assessment of one's own skills (Elliot, 2005). Because different types of achievement goals involve various conceptualizations and standards of competence, individuals' goal preferences may influence how individual approach tasks such as goal setting and choosing strategies (Brandmo, 2013). Traditionally, researchers mainly focused on two types of achievement goals: mastery goals and performance goals (Ames \& Archer, 1988). Although various researchers have had diverse conceptualizations of goals and have used different terms to describe them (Dweck, 1986; Nicholls, 1984), we will adopt the terms used by Ames and Archer. Originally, mastery goals were conceptualized as the focus on learning and development and were considered the most adaptive goal type with regard to motivation and learning outcomes. Performance goals initially focused on the demonstration of ability relative to others and were associated with anxiety and selfhandicapping learning behaviour. However, in the late 1990s, both these goal types were further divided to incorporate approach goals and avoidance goals (Elliot \& Harackiewicz, 1996; Elliot \& McGregor, 2001; Pintrich, 2000; Skaalvik, 1997).

Mastery approach goals are similar to the original mastery goals and focus on learning and development. On the other hand, mastery avoidance goals deal with situations where the individual acts due to the fear of losing mastery or the stagnation of development. Performance approach goals focus on performing better than others, whereas performance avoidance goals emphasize not demonstrating incompetence. Previous studies of students' achievement goals show that mastery approach goals are usually positively associated with task interest, selfefficacy, self-determination, engagement and deeper cognitive processing (Bandalos, Finney, \& Geske, 2003; Cury, Elliot, Da Fonseca, \& Moller, 2006; Elliot \& McGregor, 2001). Performance approach goals are positively associated with competitiveness, fear of failure, surface cognitive processing, self-efficacy and long- and short-term academic success, particularly in higher education (Elliot \& Moller, 2003; Harackiewicz, Durik, Barron, Linnenbrink-Garcia, \& Tauer, 2008; Hulleman, Schrager, Bodmann, \& Harackiewicz, 2010; Senko, Hulleman, \& Harackiewicz, 2011). Both types of avoidance goals are positively associated with worry, emotionality and disorganization, and negatively associated with performance (Cury et al., 2006; Elliot \& McGregor, 2001). However, according to multiple goal theory (Harackiewicz, Barron, Pintrich, Elliot, \& Thrash, 2002) the various types of achievement goals are not assumed to be mutually exclusive. Individuals may hold more than one goal type simultaneously, but it is assumed that one goal type may be dominant and that preferences for each goal type may vary across contexts and tasks (Senko \& Harackiewicz, 2005).

\section{The Norwegian Context of Accountability}

For several centuries, the progressive movements in education had a hegemony in Norwegian education among bureaucratic officeholders (Skagen, 2004), educational researchers and several principals, especially in Norwegian primary schools. Before the millennium, the education policy in Norway was aligned with ideas linked to a progressive school philosophy that emphasized pupils' intrinsic motivation. However, a turnaround of educational policy and management was instigated by a centre-conservative government in 2002. The first disappointing results from the Programme for International Student Assessment (PISA 2000) legitimized this turnaround. In subsequent years, the assessment system has moved towards increased accountability based on performance measures. The advent of educational accountability after the millennium has created more external pressure for improved performance, and performance measures are used as indicators of goal attainment.

Norwegian school principals are currently experiencing a national quality assessment system. The tools of this system involve performance controlled by the use of measurements such as grades, national tests, an audit explosion and value-added indicators. Pay-for-perfor- 
mance elements are used as building blocks of accountability systems in education. Accountability is rooted partly in the hierarchical construction of the educational sector. In addition,

PROBLEMS

OF EDUCATION

IN THE $21^{\text {st }}$ CENTURY

Volume 58,2014 schools are held responsible by the press and the legal system (Elstad, 2009). This means that principals in Norwegian schools face external pressures that can influence their motivational orientation. The principals' achievement orientation is their motivation to ensure that the school will perform well when measured in terms of a broad external understanding of the principal's personal responsibility for school results. Similarly, principals can also be motivated to avoid embarrassment and criticism from other bodies. Such cases are referred to as performance avoidance tendency. The development tendencies of external factors might have influenced or reinforced the motivational outlook of principals.

Given the increasing focus on the accountability of school leaders nationally and internationally (Elstad, 2009; O'Donnell \& White, 2005; Tucker \& Codding, 2002), and stakeholders' tendency to evaluate principals' proficiency in relation to student achievement scores on national tests and exams, the achievement goal theory considered to be a fruitful approach to study educational leadership. Therefore, this study explores the usefulness of principals' achievement goals for leading.

\section{Correlates}

In this study, the achievement goals with several measures have been correlated in order to do a first check of predictive value. By doing so, the study identifies a battery of useful measures of principals' motivational patterns and the organizational antecedents of principals' motivation. First, principals' background information, such as gender, age, education, and experience as teachers, have been tested in relation to principals' goal preferences. Even though the literature is inconsistent regarding the relations to such factors (see, e.g. Butler, 2007; Grant \& Dweck, 2003), women were expected to have slightly stronger preferences for mastery approach goals than men.

Second, measures of school size and school level were included. Because active recruitment of students mainly is relevant for secondary education in Norway, it is reasonable to believe that principals in higher school levels are more concerned about their school's reputation in relation to other schools. In addition, upper secondary schools do often have a higher number of students than schools at lower grades. Therefore, positive relations between performance approach goals and school size and between performance approach goals and school level were expected to be found.

Third, feedback from Chief Executive Officer (CEO) may be an important tool in an accountability system, given that it is used to discuss leadership matters and includes focus on results. On one hand, such feedback may increase the pressure on the school principal and induce performance goals (both approach and avoidance). On the other hand, if the relation between the principals and their CEO is characterized by trust and agreement about the success criteria, feedback may not necessarily force performance goals. Therefore, no predictions were made about the relation between the goals and frequency of feedback from CEO.

Fourth, principals' may experience time pressure. An external accountability system may impose pressure on principals' amount of individual time for reflective practice. Perceived time pressure may therefore influence achievement goals. Given that, the principals who hold performance goals would be more vulnerable if they not succeed (Elliot \& Church, 1997; Midgley, Kaplan, \& Middleton, 2001), we expected to find a positive relation between time pressure and performance avoidance goals.

Fifth, uncertainties about the principal's role (Rizzo, House, \& Lirtzman, 1970) can also influence the principal's motivation. However, due to the complexity of Principals' role and the possible variation in aspects of the role, we did not make any distinct prediction.

Sixth, job autonomy (Morgeson \& Humphrey, 2006) is the extent to which principals have the freedom to plan and carry out their work on a day-to-day basis. In addition, job auton- 
Christian Brandmo, Dijana Tiplic, Eyvind Elstad. The Achievement Goal Theory as an Approach to Study School Principals' Leadership Motivation

PROBLEMS

OF EDUCATION

IN THE $21^{\text {st }}$ CENTURY Volume 58,2014

30

omy contributes to principals' sense of commitment and personal engagement to their school organization (Morgeson \& Delaney-Klinger, 2005). Because a principal that holds mastery goals would be less affected by external pressure, for instance from CEO, a positive relation between mastery approach goals and job autonomy is predicted.

Seventh, trust is viewed as the basis of the relationship underlying social exchanges that entail unspecified obligations such as when an individual does another individual a favor, there is an expectation of some future accommodation (Bryk \& Schneider, 2002). Relational trust between the principal and teachers may influence principals' job motivation and their affective commitment to work place. Because principals with high preferences for mastery goals will have a focus on improvement, according to internal standards of the school and this may both require and force trust in the relation to the teachers, a positive relation between the mastery approach goals and teacher-principal trust has been predicted.

Eight, perceived self-efficacy (Bandura, 1977) among principals is concerned with principals' "beliefs in their capabilities to organize the positive psychological capabilities, motivation, means, collective resources, and courses of action required to attain effective, sustainable performance across their various leadership roles, demands, and contexts" (Hannah, Avolio, Luthans, \& Harms, 2008, p. 670). Here we discern three different aspects of principals' efficacy beliefs: efficacy for instructional supervision, efficacy for personnel and administrative management, and efficacy for the relation to CEOs. According to previous research (Elliot \& Church, 1997; Elliot \& Covington, 2001; Linnenbrink, Tyson, \& Patall, 2008) that suggests a positive relation between approach goals and self-efficacy, a prediction is that the approach goals are to be positively related to all the efficacy aspects.

Finally, in-role behaviour refers to principal's work motivation, in which is indicated by extra effort that extends the expectations of CEOs or what is prescribed in the formal job-role (Hui, Law, \& Chen, 1999). The construct of principal's in-role behaviour may be considered as consequences of principal's achievement goals. Given the assumption that in-role behaviour is founded in internal forms of motivation, principals with high preferences for mastery approach goals are expected to report higher levels of in-role behaviour.

\section{Methodology of Research}

\section{Participants}

270 principals ( $57 \%$ female and $43 \%$ male) from Norwegian schools participated in this study. Data were collected as part of a countrywide digital survey asking school principals to report a number and contact information of newly qualified teachers in their schools. The whole population of Norwegian school principals received the survey, but the response-rate was quite low. However, given the multiple purposes of the data collection and the respondents' workload required, the low response rate has been expected. Therefore, representativeness was estimated by comparing background variables to population statistics. Given the reported distribution of participants' gender, educational level, work experience as a teacher, school type (e.g. number of primary school principals, secondary principals, etc.), school size (number of students), as well as geographical distribution (number of participants from each county relative to the size and number of participants from urban versus rural areas), it is assumed that the sample represents a proper estimate of the Norwegian school principals.

\section{Measures}

The achievement goal measures were developed based on the structure of the Achievement Goal Questionnaire of Elliot and Murayama (2008), which includes four types of achievement goals: mastery approach goals, mastery avoidance goals, performance approach goals and performance avoidance goals. However, in order to capture the principals' evaluations of com- 
petence, particularly related to the context of leadership (and not personal learning or academic performance), the items are used in relation to outcomes at the school level. Mastery goals were

PROBLEMS

OF EDUCATION

IN THE $21^{\text {st }}$ CENTURY

Volume 58,2014

defined in relation to the school's development or stagnation using important quality indicators. Performance goals were defined in relation to the school's quality or reputation relative to other schools (see Table 1 for item-wording). The achievement goals were scored on a scale of 1 (not true) to 7 (extremely true).

In addition to the achievement goal measures, we included personal background: gender (high scores indicate male), age, length of education, and experience as teacher. Contextual and organizational measures included school size (number of students), school level (see aforementioned information about sample), and several scales from organizational psychology: Frequency of feedback from CEOs (Patterson et al., 2005) (sample item: 'The CEO gives the principal regular feedback on the quality of his/her work.'), time pressure (Tiplic, Brandmo, \& Elstad, Submitted) (sample item: 'Administrative work must often be done after working hours.'), role clarity (Rizzo, House, \& Lirtzman, 1970) (sample item: I know what my responsibilities are.), job autonomy (Morgeson \& Humphrey, 2006) (sample item: 'The job allows me to make decisions about what methods I use to complete my work.'), and teacher-principal trust (Bryk \& Schneider, 2002) (sample item: 'As principal, I do have a personal interest in the professional development of the teachers.'). The measures of self-efficacy included three dimensions of self-efficacy for educational leadership: 1) efficacy for instructional supervision (sample item: 'How certain are you that you can give concrete advice to teachers struggling to maintain order in the classroom?'), 2) efficacy for personnel and administrative management (Federici \& Skaalvik, 2011) (sample item: 'How certain are you that you can put into effect necessary actions at individual and group level if teachers or other employees are struggling with collaboration?'), and 3) efficacy for the relation to CEOs (sample item: 'How certain are you that you can influence the CEO's decisions about your school?'). Finally, we included a measure of in-role behaviour (sample item: 'Often, I put extra effort into my job.'). All the aforementioned scales, except teacher-principal trust, and self-efficacy were scored on a scale of 1 (not true) to 6 (true). All efficacy measures were scored on a scale of 1 (not true at all) to 7 (absolutely true) and teacher-principal trust was scored on a scale of 1 (completely disagree) to 6 (completely agree).

\section{Results of Research}

Initially, the Kaiser-Meyer-Olkin measure of sample adequacy, with a value of 0.83 , indicated that factor analysis was appropriate for the data. An exploratory factor analysis of the achievement goal items revealed two factors that met the Kaiser-Guttman criterion of eigenvalue greater than unity (see Table 1 for loadings). The two factors had eigenvalues of 4.56 and 2.52, respectively, and accounted for $59 \%$ of the variance. All the performance goal items (both approach and avoidance) were clearly extracted in the first factor, with loadings from 0.82 to 0.62 . Moreover, four of the mastery goal items had proper loadings on the second factor $(0.83$ to 0.62 ), while the final two items (MAP1 and MAV1) had low loadings on both factors.

Based on the results of the factor analysis, composite scores for mastery goals and performance goals were produced. The two items that did not fit well into the two-factor model were excluded. The correlation between the mastery goals and performance goals was 0.14 ( $p$ $<0.05)$, in which indicate that this constructs are distinct. Then the scores were correlated with the scores of background variables and the other constructs. Table 2 provides descriptive statistics for all included composite scores used. 
Christian Brandmo, Dijana Tiplic, Eyvind Elstad. The Achievement Goal Theory as an Approach to Study School Principals' Leadership Motivation

PROBLEMS

IN THE $21^{\text {st }}$ CENTURY

Volume 58,2014

Table 1. Results of factor analysis.

\begin{tabular}{|c|c|c|c|}
\hline Item & & Factor 1 & Factor 2 \\
\hline PAV1 & $\begin{array}{l}\text { My goal is to avoid that the school should achieve worse results (e.g. lower GPA, } \\
\text { poorer results on students' evaluation and national tests) than other schools, we } \\
\text { use to compare us with. }\end{array}$ & 0.82 & 0.10 \\
\hline PAP1 & $\begin{array}{l}\text { My goal is that the school should achieve better results (e.g. higher GPA, better } \\
\text { results on students' evaluation and national tests) than other schools, we use to } \\
\text { compare us with. }\end{array}$ & 0.79 & 0.06 \\
\hline PAV2 & $\begin{array}{l}\text { My goal is to avoid that the school should have a worse reputation than neighbour- } \\
\text { ing schools with regard to learning environment and academic quality. }\end{array}$ & 0.79 & 0.02 \\
\hline PAP 3 & $\begin{array}{l}\text { My goal is that the school, compared to other schools, should appear as good and } \\
\text { well managed in front of school authorities and parents. }\end{array}$ & 0.70 & 0.11 \\
\hline PAP2 & $\begin{array}{l}\text { My goal is that the school should have a better reputation than neighbouring schools } \\
\text { with regard to learning environment and academic quality. }\end{array}$ & 0.69 & -0.06 \\
\hline PAV3 & $\begin{array}{l}\text { My goal is to avoid that the school, compared to other schools, should appear as } \\
\text { poorly managed in front of school authorities and parents. }\end{array}$ & 0.62 & 0.24 \\
\hline MAP3 & My goal is to increase students' learning benefits and well-being. & 0.02 & 0.83 \\
\hline MAP2 & My goal is to improve the school's academic and pedagogical quality. & 0.06 & 0.80 \\
\hline MAV2 & $\begin{array}{l}\text { My goal is to avoid that school's academic and pedagogical quality should stagnate } \\
\text { or have a negative development. }\end{array}$ & 0.07 & 0.62 \\
\hline MAV3 & My goal is to avoid a decrease in students' learning benefits and well-being. & 0.09 & 0.62 \\
\hline MAP1 & $\begin{array}{l}\text { My goal is that the school should have a positive development with regard to the } \\
\text { results (e.g. higher GPA, better results on students' evaluation and national tests). }\end{array}$ & 0.38 & 0.43 \\
\hline MAV1 & $\begin{array}{l}\text { My goal is to avoid that the school should stagnate or have a negative development } \\
\text { with regard to the results (e.g. lower GPA, poorer results on students' evaluation } \\
\text { and national tests). }\end{array}$ & 0.47 & 0.31 \\
\hline
\end{tabular}

As expected, no significant correlations between the goals and background variables such as age, work experience or level of education have been found (see Table 3). Neither have any significant relation between the goals and gender been found. With regard to respect to contextual and organizational variable, several significant relations revealed. First, school size was significantly related to the performance goals and not to master goals. This indicates that principals in large schools tend to have higher preferences for performance goals than principals in small schools. Second, role clarity, job autonomy, and teacher-principal trust all turned out to be significantly correlated with the mastery's goals while only teacher teacher-principal trust was significantly correlated with performance goals. School level, frequency of feedback 
Christian Brandmo, Dijana Tiplic, Eyvind Elstad. The Achievement Goal Theory as an Approach to Study School Principals' Leadership Motivation

from CEO, and perceived time pressure did not turn out to be significantly related to any goals.

These results suggest that principals, who hold high preferences for mastery goals, also perceive higher level of role clarity and more trust in the relations to their teachers.

Table 2. Descriptive statistics of composite scales.

\begin{tabular}{lcccccc}
\hline Construct & N & Mean & SD & Skewness & Kurtosis & a \\
\hline Mastery achievement goal & 255 & 6.51 & 0.52 & -0.99 & 0.81 & 0.80 \\
\hline Performance achievement goal & 250 & 5.25 & 1.10 & -0.91 & 1.51 & 0.88 \\
\hline Frequency of feedback from CEO & 258 & 3.82 & 1.34 & -0.28 & -0.80 & 0.87 \\
\hline Perceived time pressure & 268 & 4.05 & 1.01 & -0.18 & 0.03 & 0.72 \\
\hline Perceived role clarity & 267 & 4.81 & 0.57 & -0.17 & 0.01 & 0.74 \\
\hline Perceived job autonomy & 267 & 4.88 & 0.80 & -0.56 & 0.04 & 0.87 \\
\hline $\begin{array}{l}\text { Teacher-principal trust } \\
\text { Efficacy for instructional supervision }\end{array}$ & 256 & 5.14 & 0.53 & -0.52 & 0.25 & 0.69 \\
\hline $\begin{array}{l}\text { Efficacy for personnel and administrative man- } \\
\text { agement }\end{array}$ & 258 & 5.14 & 0.72 & 0.15 & -0.08 & 0.83 \\
\hline $\begin{array}{l}\text { Efficacy for the relation to municipal/county au- } \\
\text { thority }\end{array}$ & 266 & 5.47 & 0.94 & -0.65 & 0.45 & 0.74 \\
\hline \begin{tabular}{l} 
In-role behaviour \\
\hline
\end{tabular} & 267 & 5.47 & 0.52 & -0.70 & -0.57 & 0.75 \\
\hline
\end{tabular}

All included self-efficacy beliefs were significantly correlated with mastery goals (see Table 3) and were not significantly correlated with performance goals. In addition, both mastery and performance goals were significantly correlated with in-role behaviour, however the relation to mastery goals was slightly stronger than to performance goals.

\section{Discussion}

\section{Factor Analysis}

Although the factor analysis did not succeed in covering all the hypothesized dimensions, a clear distinction between mastery goals and performance goals have been found. A possible reason for not finding the hypothesized distinction between approach and avoidance goals may be that success and failure are less clear concepts within the leadership than within students' learning. Principals, as professional leaders, may have a clearer conception of the risk of failure. For instance, they may view it as intertwined with the chances of success. Furthermore, principals often have the opportunity to attribute failure to organizational factors that they simply cannot influence; thus, they can deny responsibility if they fail. 
Christian Brandmo, Dijana Tiplic, Eyvind Elstad. The Achievement Goal Theory as an Approach to Study School Principals' Leadership Motivation

PROBLEMS

OF EDUCATION

IN THE $21^{\text {st }}$ CENTURY

Volume 58,2014

\section{Table 3. Correlates.}

\begin{tabular}{lll}
\hline Construct & Mastery goals & Performance goals \\
\hline Background & & \\
\hline Gender & -0.05 & 0.06 \\
\hline Age & 0.05 & 0.05 \\
\hline Education & 0.04 & 0.04 \\
\hline Experience as teacher & -0.01 & 0.04 \\
\hline Contextual /organizational characteristics & & $0.18^{* *}$ \\
\hline School size & 0.11 & 0.10 \\
\hline School level & -0.05 & 0.02 \\
\hline Frequency of feedback from CEO & -0.01 & 0.07 \\
\hline Perceived time-pressure & -0.06 & 0.12 \\
\hline Perceived role clarity & $0.23^{* * *}$ & 0.12 \\
\hline Perceived job autonomy & $0.13^{*}$ & $0.14^{*}$ \\
\hline Teacher-principal trust & $0.30^{* * *}$ & \\
\hline Competence motivation & & $0.13^{*}$ \\
\hline Efficacy for instructional supervision & $0.27^{* * *}$ & 0.12 \\
\hline Efficacy for personnel and administrative management & $0.18^{* *}$ & \\
\hline Efficacy for the relation to school-owner & $0.15^{* *}$ & \\
\hline Outcome & & $0.22^{* * *}$ \\
\hline In-role behaviour & & \\
\hline${ }^{*} p<0.05,{ }^{* *} p<0.01,{ }^{* * *} p<0.001$ & & \\
\hline
\end{tabular}

The fact that the two excluded items did not fit with the model may indicate that the principals did not consider student test scores (on large-scale tests) an important tool for improving the students' learning. Rather, they might view these student scores as indicators of success in relation to the authorities and the educational CEO (perhaps seeing them as a 'necessary evil'). However, in our analysis, we found a tendency for differences in the factor structure between primary and secondary school principals. An analysis of a subsample of secondary school principals showed a weak third factor where all items referred to student achievement (MAP1, MAV1, PAP1 and PAV1). This may indicate that student achievement is more important for principals in secondary schools than in primary schools. Due to the small sample size and crossloading with the first factor, we did not perform further analysis of this factor.

\section{Correlations}

The findings regarding the relationship between achievement goals and other motivational constructs are in line with previous research on student learning (e.g. Cury et al., 2006). Mastery goals were more strongly correlated than performance goals to all included efficacy beliefs and to in-role behaviour and teacher-principal trust. This suggests that principals with 
greater preferences for mastery goals feel more confident in supervising their teachers, handling administrative issues, and with being their school's spokesperson in relation to their executives. These principals also make an extra effort and have better personal relationships with their teachers.

\section{Limitations of the Study}

There are several limitations in this study. This type of analysis has limitations from a conceptual perspective (parsimonious modeling) and in terms of its methodological (crosssectional) approach. In addition, when associations between constructs are independent of association in the real world, biases may emerge in the measurement (Podsakoff et al., 2003). We acknowledge these limitations and argue that they can serve as a point of departure for future research.

Also, multiple factors may influence human behaviour. Quasi-experimental studies are needed to determine causality. Cross-sectional studies, such as this study, only represent a momentary glimpse of school organizations; they do not test causal relationships. Longitudinal research is also needed to address the complexity of interactional dynamics between leaders, their executives and teachers and the associated impact on principals' motivation.

Another limitation of this study is the use of self-reported questionnaire data. The subjective component of such data is undeniable. Independent judgments can provide interesting data about an employee's performance, but it is difficult to carry out this process while honouring promises of anonymity. The heavy reliance on principals' self-reports is questionable. Another related limitation is a lack of opportunity to couple school principals' self-reporting with objective goals in terms of their task performance, because it was not possible to examine the associations between principals' achievement motivation and objective performance.

Furthermore, other factors outside the school system could influence principals' motivational orientations and should have been included in the study. Only a limited number of concepts were examined. One challenge of measuring such factors is that measurement becomes increasingly difficult in proportion to the remoteness of the factor in the education sector's hierarchical organization. One solution could be to examine some cases in depth to attain a more comprehensive understanding of the principals thinking in relation to goals and what factors that force various types of goals.

A final limitation is a small sample of principals always leaves uncertainty about whether the samples are representative. In sum, these shortcomings provide direction for future research.

\section{Implications for Practice and Further Research}

Despite its shortcomings, this study may contribute to better understanding of principals' achievement motivation. If the associations represent causal relationships, our findings may have implications for practice. Moderate empirical associations between principals' efficacy for instructional supervision and mastery goals have been found. With the current emphasis on the efficiency of instructional leadership (Robinson et al., 2008), this finding serves as empirical support for the importance of education systems that nurture principals' mastery motivation. The statistical association between in-role behaviour and mastery goals could be interpreted in a similar way.

The moderate statistical association between teacher-principal trust and principals' mastery goals is consistent with studies that found that the human qualities of school staff influence principals' and teachers' motivation (Bryk \& Schneider, 2002). The quality of human relationships between educators and their principals is an important resource in school improvement. The significant relations between principals' performance goals and in-role behaviour should also be noted. This statistical association must be interpreted in the context of educational ac- 
Christian Brandmo, Dijana Tiplic, Eyvind Elstad. The Achievement Goal Theory as an Approach to Study School Principals' Leadership Motivation

OF EDUCA

PROBLEMS

IN THE $21^{\text {st }}$ CENTURY

Volume 58, 2014

countability. Principals in Norwegian schools face external pressures that can influence their motivational approach. The principals' achievement orientation is their motivation to ensure that the school will perform well when measured in terms of a broad external understanding of the principal's personal responsibility for school results. Further research is needed to understand how accountability devices may influence school-organisational factors and principals' performance motivation.

Antecedents of principals' achievement motivation are complex, and it is difficult to develop concrete principles on the basis of this investigation. It will therefore be a central challenge in future research to investigate more systematically a greater number of organisational variables in the models. This will enhance the understanding of the relationships between the educational management system and principals' motivational orientations.

The relations between the goal constructs and other constructs (both psychological and organizational) are interesting. Given that the mastery and performance goal types appear to relate to diverse motivational and organizational constructs in various ways, we suggest that achievement goal theory combined with organizational theory can provide a fruitful avenue for further research on school leadership and leadership motivation. Finally, future research should explore the goal constructs and examine how these goals may be related to leadership performance (the formal success indicators). A relevant proposition is that a high preference for mastery goals combined with high preference for performance goals (Harackiewicz et al., 2002; Pintrich, 2000) among school principals is favourable with regard to achievement.

\section{Conclusions}

The primary purpose of this study was to test whether the achievement goal theory was transferable to the context of educational leadership. Furthermore, the aim was to develop measures of principals' achievement goals for leading. Although the study did not succeed in confirming all the hypothesized dimensions of achievement goals, it found a clear distinction between principals' mastery goals and performance goals. Given the clear factor extraction and the findings in sense of correlations with significant organizational constructs, a main conclusion is that that the goal theory may be a useful framework for studying leadership motivation. More specifically, the study suggests that the achievement goal theory can be expanded to capture important aspects of educational management. With respect to measures, this study does not represent a complete validation of new applications of scales, but it gives directions for further development work. In that sense, this study represents a contribution to the field, both conceptually and methodologically.

Finally, this investigation may be considered an interesting starting point for further analysis of antecedents and consequences of principals' motivational orientation. This result opens up a promising avenue for the application of the achievement goal theory in the field of educational management.

\section{References}

Ames, C., \& Archer, J. (1988). Achievement goals in the classroom: Students' learning strategies and motivation processes. Journal of Educational Psychology, 80 (3), 260-267. doi: 10.1037/00220663.80.3.260.

Allen, N. J., \& Meyer, J. P. (1990). The measurement and antecedents of affective, continuance, and normative commitment to the organization. Journal of Occupational Psychology, 63, 1-18.

Bandalos, D. L., Finney, S. J., \& Geske, J. A. (2003). A model of statistics performance based on achievement goal theory. Journal of Educational Psychology, 95 (3), 604-616. doi: 10.1037/0022-0663 95.3.604.

Bandura, A. (1977). Self-efficacy: Toward a unifying theory of behavioural change. Psychological Review, 84 (2), 191-215. doi: 10.1037/0033-295X.84.2.191. 
Brandmo, C. (2013). Achievement goals: What are they and what significance do they have for students' learning and performance? In E. Bjørnestad \& J. H. Stray (Eds.), New Voices in Norwegian Educational Research (pp. 9-25). Rotterdam: Sense Publishers.

Bryk, A. S., \& Schneider, B. (2002). Trust in schools: A core resource for improvement. New York: The Russel Sage Foundation.

Butler, R. (2007). Teachers' achievement goal orientations and associations with teachers' help seeking: Examination of a novel approach to teacher motivation. Journal of Educational Psychology, 99 (2), 241-252. doi: 10.1037/0022-0663.99.2.241.

Cury, F., Elliot, A. J., Da Fonseca, D., \& Moller, A. C. (2006). The social-cognitive model of achievement motivation and the $2 \times 2$ achievement goal framework. Journal of Personality and Social Psychology, 90 (4), 666-679. doi: 10.1037/0022-3514.90.4.666

de Wolf, I. F., \& Janssens, F. J. G. (2007). Effects and side effects of inspections and accountability in education: an overview of empirical studies. Oxford Review of Education, 33 (3), 379-396.

Dweck, C. S. (1986). Motivational processes affecting learning. The American Psychologist, 41 (10), 1040-1048. doi: 10.1037/0003-066X.41.10.1040.

Elliot, A. J., \& Harackiewicz, J. M. (1996). Approach and avoidance achievement goals and intrinsic motivation: A mediational analysis. Journal of Personality and Social Psychology, 70 (3), 461-475. doi: $10.1037 / 0022-3514.70 .3 .461$.

Elliot, A. J., \& McGregor, H. A. (2001). A 2 x 2 achievement goal framework. Journal of Personality and Social Psychology, 80 (3), 501-519. doi: 10.1037/0022-3514.80.3.501.

Elliot, A. J., \& Moller, A. C. (2003). Performance-approach goals: Good or bad forms of regulation? International Journal of Educational Research, 39 (4-5), 339-356. doi: 10.1016/j.ijer.2004.06.003.

Elliot, A. J., \& Murayama, K. (2008). On the measurement of achievement goals: Critique, illustration, and application. Journal of Educational Psychology, 100 (3), 613-628. doi: 10.1037/0022-0663 .100 .3 .613

Elliot, A. J. (2005). A conceptual history of the achievement goal construct. In A. J. Elliot \& C. S. Dweck (Eds.), Handbook of competence and motivation (pp. 52-72). New York: Guilford Press.

Elstad, E. (2009). Schools which are named, shamed and blamed by the media: school accountability in Norway. Educational Assessment, Evaluation and Accountability, 21, 173-189.

Federici, R., \& Skaalvik, E. (2011). Principal self-efficacy and work engagement: Assessing a Norwegian Principal Self-Efficacy Scale. Social Psychology of Education, 14 (4), 575-600. doi: 10.1007/ s11218-011-9160-4.

Harackiewicz, J. M., Durik, A. M., Barron, K. E., Linnenbrink-Garcia, L., \& Tauer, J. M. (2008). The role of achievement goals in the development of interest: Reciprocal relations between achievement goals, interest, and performance. Journal of Educational Psychology, 100 (1), 105-122. doi: 10.1037/0022-0663.100.1.105.

Hui, C., Law, K. S., \& Chen, Z. X. (1999). A Structural Equation Model of the Effects of Negative Affectivity, Leader-Member Exchange, and Perceived Job Mobility on In-role and Extra-role Performance: A Chinese Case, Organizational Behaviour and Human Decision Processes, 77 (1), $3-21$.

Hulleman, C. S., Schrager, S. M., Bodmann, S. M., \& Harackiewicz, J. M. (2010). A meta-analytic review of achievement goal measures: Different labels for the same constructs or different constructs with similar labels? Psychological Bulletin, 136 (3), 422-449. doi: 10.1037/a0018947.

Morgeson, F. P., \& Humphrey, S. E. (2006). The Work Design Questionnaire (WDQ): Developing and validating a comprehensive measure for assessing job design and the nature of work. Journal of Applied Psychology, 91 (6), 1321-1339. doi: 10.1037/0021-9010.91.6.1321.

Nicholls, J. G. (1984). Achievement motivation: Conceptions of ability, subjective experience, task choice, and performance. Psychological Review, 91 (3), 328-346. doi: 10.1037/0033-295X.91.3.328.

O'Donnell, R. J., \& White, G. P. (2005). Within the accountability era: principals' instructional leadership behaviours and student achievement. NASSP Bulletin, 89 (645), 56-71. doi: $10.1177 / 019263650508964505$.

Pintrich, P. R. (2000). The role of goal orientation in self-regulated learning. In M. Boekaerts, P. R. Pintrich, \& M. Zeidner (Eds.), Handbook of self-regulation (pp. 450-502). San Diego: Academic Press.

Podsakoff, P. M., MacKenzie, S. B., Paine, J. B., \& Bacharach, D. G. (2000). Organisational citizenship behaviours: A critical review of the theoretical and empirical literature and suggestions for future research, Journal of Management, 26 (3), 513-563. 
Christian Brandmo, Dijana Tiplic, Eyvind Elstad. The Achievement Goal Theory as an Approach to Study School Principals' Leadership Motivation

PROBLEMS

OF EDUCATION

IN THE $21^{\text {st }}$ CENTURY

Volume 58, 2014

Retelsdorf, J., Butler, R., Streblow, L., \& Schiefele, U. (2010). Teachers' goal orientations for teaching: Associations with instructional practices, interest in teaching, and burnout. Learning and Instruction, 20 (1), 30-46. doi: 10.1016/j.learninstruc.2009.01.001.

Robinson, V. M. J., Lloyd, C. A., \& Rowe, K. J. (2008). The impact of leadership on student outcomes: an analysis of the differential effects of leadership types. Educational Administration Quarterly, 44 (5), 635-674.

Senko, C., \& Harackiewicz, J. M. (2005). Regulation of achievement goals: The role of competence feedback. Journal of Educational Psychology, 97 (3), 320-336. doi: 10.1037/0022-0663.97.3.320.

Senko, C., Hulleman, C. S., \& Harackiewicz, J. M. (2011). Achievement goal theory at the crossroads: Old controversies, current challenges, and new directions. Educational Psychologist, 46 (1), 2647. doi: 10.1080/00461520.2011.538646.

Skagen, K. (2004). Det nye pedokratiet i skoleverket, Utdanning April 2, 2004.

Skaalvik, E. M. (1997). Self-enhancing and self-defeating ego orientation: Relations with task and avoidance orientation, achievement, self-perceptions, and anxiety. Journal of Educational Psychology, 89 (1), 71-81. doi: 10.1037/0022-0663.89.1.71.

Tiplic, D., Brandmo, C., \& Elstad, E. (Submitted). Antecedents of Norwegian Beginning Teachers’ Turnover Intentions.

Tucker, M. S., \& Codding, J. B. (Eds.). (2002). The principal challenge: Leading and managing schools in an era of accountability. Hoboken, NJ: Jossey-Bass/Wiley.

Advised by Laima Railiene, University of Siauliai, Lithuania

Received: March 05, 2014

Accepted: March 25, 2014

\section{Christian Brandmo}

Dijana Tiplic
PhD, Associate Professor, Department of Teacher Education and School, P.O. Box 1099 Blindern, 0317 Oslo, Norway.

E-mail: christian.brandmo@ils.uio.no

Website: http://www.uv.uio.no/ils/personer/vit/chrbrand/index.html

$\mathrm{PhD}$, Associate Professor, Department of Teacher Education and School, P.O. Box 1099 Blindern, 0317 Oslo, Norway.

E-mail: dijana.tiplic@ils.uio.no

Website: http://www.uv.uio.no/ils/personer/vit/dijanati/index.html

Eyvind Elstad
PhD, Professor, Department of Teacher Education and School, P.O. Box 1099 Blindern, 0317 Oslo, Norway.

E-mail: eyvind.elstad@ils.uio.no

Website: http://www.uv.uio.no/ils/personer/vit/eyvindel/index.html 